\title{
ALIANCES FEMINISTES EN EL TREBALL SEXUAL
}

FEMINIST ALLIANCES IN SEX WORK

\author{
Elena Martínez Pérez \\ Universidad de Castilla - La Mancha
}

\section{RESUMEN}

Aquesta investigació analitza els actors socials i discursos que estan intervenint en la controvèrsia que envolta al treball sexual en l'esfera pública, per tal d'entendre com s'articulen els conflictes d'interessos i visions i quins actors o punts de vista inclou, exclou, reforça o debilita eixa articulació. Controvèrsia a la qual s'han sumat, en els últims anys, l'emergència d'un sector fonamental: les treballadores sexuals. Mitjançant l'aproximació etnogràfica a l'espai de l'activisme en el treball sexual i les entrevistes en profunditat, comprovarem si s'estan construint com subjectes apoderats, amb una identitat política definida, de quina manera, si estan introduint les seues reivindicacions en el discurs públic, a través de quines estratègies i quines aliances han establert amb altres col-lectius socials.

Palabras clave: treball sexual, prostitució, activisme feminista, apoderament, etnografia virtual.

\section{ABSTRACT}

This research analyzes the social actors and discourses in the controversy around sex work in public sphere, in order to understand how conflicts of interests and visions are articulated and which actors or views, strengthened or weakened, are included in this joint. In recent years, one fundamental sector has emerged in this controversy: sex workers. Through ethnographic approximation to sex workers' activism space and depth interviews, we've checked if they are being built as subjects with a defined political identity, in which way, if their demands are being introduced in public discourse, through which strategies and which alliances have done with other social groups.

Keywords: Sex Work, Prostitution, Feminist Activism, Empowerment, Virtual Ethnography.

\section{Introducció}

Quan parlem de treball sexual no podem deixar de banda la forta controvèrsia que aquest ha suscitat des de sempre i que ha transcendit a diferents sectors socials. Avui 
en dia, encara és un debat candent, tant als moviments feministes com a les mateixes institucions. I perquè la prostitució ha estat sempre un tema controvertit? Com assenyala l'antropòloga Debora Daich (2012: 71), la prostitució «és problemàtica en si mateixa perquè condensa diversos significats, perquè parla d'un divers mercat sexual en què diferències de classe, ètnia i gènere, es conjuguen en diferents combinacions, donant lloc a innombrables escenaris». Per comprendre aquesta circumstància en la seua complexa totalitat, s'han analitzat, primerament, els actors socials i discursos que estan intervenint en la controvèrsia que envolta al treball sexual en l'esfera pública, per determinar com s'articulen els conflictes $d^{\prime}$ interessos i visions i què actors o punts de vista inclou, exclou, reforça o debilita aquesta articulació. A aquesta controvèrsia s'ha sumat, en els últims anys, com explicàvem, l'emergència d'un sector social fonamental: les treballadores sexuals. A causa d'això, des de les perspectives que advoquen pel reconeixement del treball sexual, hem plantejat una investigació que indaga en una de les estratègies utilitzades per defendre aquesta posició $\mathrm{i}$ que sorgeix des d'aquelles treballadores sexuals que es troben en un procés d'apoderament, mitjançant la seua participació en els moviments feministes. Concretament, tractarem com es teixeixen les xarxes de sororitat entre les mateixes treballadores sexuals i els diversos grups i col.lectius implicats dins dels feminismes, els quals, gràcies a aquestes aliances, han permès a ambdós la construcció i implementació de les seves reivindicacions en el discurs públic i han aconseguit una gran incidència en la configuració de l'agenda política. Aliances que han facilitat la deconstrucció dels imaginaris sobre els modes d'organització, estructures, funcionament $\mathrm{i}$ dinàmiques dels moviments feministes; construint un nou model històric d'organització d'espais i xarxes de solidaritat, amb pautes de cures i dinàmiques diferents de treball i collaboració, integrat per treballadores sexuals: el feminisme puta, com elles mateixes I'han batejat en les entrevistes.

D'aquest mode, hem treballat amb la hipòtesi de que les treballadores sexuals de diferents punts de l'Estat espanyol s'estan construint com a subjectes apoderats, amb una identitat política definida i estan aconseguint introduir les seves reivindicacions en el discurs públic. A més a més, ens vam plantejar aquesta investigació amb un ferm objectiu: enriquir els arguments del debat i la controvèrsia que envolta la prostitució, oferint un nou enfocament desestigmatitzant sense prejudicis, victimitzacions i qüestions morals, centrant-nos en els drets humans; prioritzant les veus de les protagonistes: les treballadores sexuals i els col-lectius prodrets que treballen al seu costat.

Així doncs, per a l'elaboració d'aquesta investigació ens hem basat en una combinació de tècniques de tipus qualitatiu. Durant anys, s'ha utilitzat l'observació activa del debat i dels posicionaments públics de les organitzacions i activistes pro-drets en l'esfera 
digital. Ens hem servit de l'esfera digital, com a novetat, perquè «el fenomen d'Internet i de les xarxes socials ha obert un nou escenari, on la representació de la prostitució està donant lloc a altres narratives [...] en primera persona de la lluita pels drets humans, laborals i socials» (Clua, 2015: 142). D'aquest mode, des de finals de 2015 a mitjans del 2016, s'han realitzat entrevistes en profunditat, tant a treballadores del sexe com a portaveus de col.lectius prodrets. Les entrevistes s'insereixen en una aproximació etnogràfica a l'espai digital (xarxes socials) de l'activisme feminista en el treball sexual, en la qual l'observació participant ha funcionat com a vincle amb les protagonistes. Així, hem comptat amb els testimonis de María Palomares (Calala Fon de les Dones, Barcelona), Montse Neira (treballadora sexual, investigadora i politòloga), Clarisa Velocci (Genera Derechos, Barcelona), Paula Ezkerra (treballadora sexual i ex-consellera de Ciutat Vella per la CUP -Candidatura d'Unitat Popularen Barcelona) i Rafa Ruiz (Col/lectiu Lambda, Valencia).

Mitjançant aquestes tècniques, hem pogut contactar amb treballadores sexuals per tal de conèixer si existeixen xarxes feministes, com és la seua autoorganització i autogestió, les seues formes de relació entre elles i si existeix realment l'organització de base en aquests grups; determinar quina és la relació amb les institucions i altres lobbies; conèixer quins són els instruments de projecció pública dels que es fan servir per a penetrar en el discurs públic, com es posicionen en el mateix, veient la recepció que tenen a la societat, i esbrinar quins temes són els protagonistes en l'agenda de les diferents lluites que s'estan lliurant en el treball sexual.

\section{Com s'insereix el treball sexual dins dels contexts feministes?}

Apropar-se al treball sexual, en el seu eix d'intersecció amb els feminismes, és conèixer diversos escenaris històrics, com comentàvem a l'inici de l'article. Jean-Luis Güereña (2003: 15) ho explica així:

La història de la prostitució, com la història de la sexualitat, forma part d'aquests nous territoris, del qual coneixement és imprescindible per apropar-nos a una comprensió de les realitats socials, dins de la història del Dret (reglamentació i administració), de la història de la Medicina (higiene) sense oblidar la història de les dones i la història social, en la mida en què aquesta pretén ser a la mateixa vegada, història de les costums i de les mentalitats. La història de la prostitució va molt més enllà de la història de les poblacions marginades com, de vegades, se la redueix.

En eixe sentit, el terme treball sexual suposa un concepte molt nou en comparació al temps que porta existint com a realitat. Quan parlem de treball sexual, ens referim a 
la prostitució exercida de forma lliure i voluntària, un fenomen que ha suscitat una forta controvèrsia social i que, en moltes ocasions, ha estat el centre de les crítiques des de diferents àmbits de la societat. Avui en dia, els posicionaments sobre el treball sexual continuen protagonitzant els debats, fins i tot tenint la capacitat de configurar l'agenda pública, modelar les lleis que regulen el seu exercici i determinar el finançament dels projectes acadèmics. Celeste Arella (2007: 8) assenyala, a més a més, que es tracta d'una qüestió social molt present en l'esfera pública:

Es cada vegada més present als debats polítics, socials i mediàtics; s'organitzen protestes i manifestacions en l'àmbit europeu; es promoven accions policials adreçades expressament contra les possibles molèsties que genera aquesta activitat als veïns; es creen estratègies per desterrar a les treballadores sexuals del perímetre urbà i relegar-les a zones quasi desertes.

Històricament, el debat sobre la prostitució comprèn una llarga genealogia, tot i que el seu punt d'inflexió, tal com es concep actualment, es troba en la dicotomització a partir de les posicions adoptades en els diferents moviments feministes respecte al mercat del sexe: el moviment antisex i el moviment prosex. Així, com explica Wendy Chapkis (1997), les feministes radicals (antisex) són aquelles que es manifesten hostils a les relacions sexuals, ja que les troben com font de l'opressió femenina en un ordre patriarcal, i les feministes llibertàries (prosex), que entenen les relacions sexuals com positives, en tant que les comprenen com a lloc de plaer i poder per a les dones.

Aquesta divisió dels dos estereotips antagònics del rol sexual femení, són els que originen els rols de víctima o disruptiva que cada posició atorga a la relació dona-sexualitatgènere. A causa d'això, des dels anys 80 , la qüestió de la prostitució ha estat dicotomitzada entre l'abolicionisme (antisex) o la defensa del treball sexual (prosex), ja que, com assegura Carolina Justo «la polarització existent entre perspectives [...] del treball sexual serien impensables sense l'existència d'aquesta distinció d'origen entre els modes de concebre la sexualitat i en particular la sexualitat de les dones»(2013: 8). Com a conseqüència d'aquestes implicacions en les concepcions sobre la sexualitat femenina, el treball sexual suposa una problemàtica social que genera punts de vista oposats, encara que tradicionalment ha romàs oculta i invisibilitzada durant molt de temps.

D'altra banda, observem com el moviment feminista es troba en un moment històric, en què s'està posant com mai en pràctica la capacitat d'acció col.lectiva de les dones, el ens volem vives ${ }^{1}$ com paradigma actual, la sororitat en el seu màxim esplendor, el pacte entre 
dones del qual parlava Marcela Lagarde, una «dimensió política que cerca la confluència i la sintonia [...] l'aliança feminista entre les dones per tal de canviar la vida i el món amb un sentit just i llibertari» (2006: 128); amb la seua consegüent incidència política: s'estan transformant les estructures, dinàmiques i formes d'organització, així com els continguts, el caràcter i les finalitats de les lluites. Les xarxes de solidaritat entre dones està provocant la deconstrucció de les dinàmiques i modes de fer tradicionals $i$, de vegades masculinitzats, $i$ s'estan imposant les xarxes de cures i d'afecte. L'organització de les treballadores sexuals i la seua incidència a tots els nivells socials, és l'exemple més representatiu d'aquest canvi de paradigma dels moviments feministes. De la mateixa manera que van néixer els feminismes negres, islàmics, gitanos, etc., assistim al naixement del feminisme puta (batejat d'aquest mode per elles mateixes als seus testimonis), un dels moviments polítics més importants del moment, perquè responen a una sèrie $d^{\prime}$ 'opressions (interseccionalitat) que no solen contemplar-se als corrents tradicionals (l'estigma en tots els seus nivells). Unes opressions que, com explica Clarisa Velocci, haurien d'estar incloses en les agendes polítiques de tots els feminismes, en tractar-se d'una qüestió transversal i no un element aillat, que ens afecta a totes:

Hem de deixar de pensar que són dues agendes completament diferents, hem de començar a compartir, ja que el moviment feminista més apropat ha de començar a posicionar-se. Ja no val pensar en el treball sexual com un tema a part, ja que com que hi ha un conflicte intern en els feminismes, ningú diria això en temes igualment vitals, per exemple, com l'avortament, seria impensable. Hem de reflexionar com a dones i feministes sobre les nostres pràctiques polítiques, hem de posicionar-nos i hem de demanar a les companyes que ja formen part de tot un moviment feminista aliat que eixe posicionament siga més fort [...] així que li posarem nom per poder reivindicar-lo: el feminisme puta. (Clarisa Velocci)

Per tant, també des dels feminismes es torna necessari projectar una mirada integradora cap al treball sexual, que s'encarregue de fixar com a prioritat la conformació d'un espai en què siga fomentada l'aliança entre dones, en què mitjançant l'esberlament del model de les santes i les putes, les bones dones i les dolentes, es puga atacar i acabar amb l'estigma que ens classifica d'acord a la nostra sexualitat i suposa un dels fonaments més poderosos sobre els que s'erigeix el patriarcat.

\section{Activisme i aliances feministes en el treball sexual}

Les treballadores sexuals són les protagonistes en els canvis socials que estem veient, construint-se com a subjectes amb una identitat política definida en la lluita pels seus drets i 
una veu pròpia, gràcies a l'apoderament feminista. Apoderament que no arriba a totes les dones per igual, ja que no sempre som conscients del, com assegura Magdalena Lleó (1997: 152), «control masculí sobre els nostres cossos i la nostra psique», de l'esfera del «poder invisible» que ens envolta. Un concepte de Lukes (1986) que concerneix a allò «natural», «obvi», «indiscutible», el lloc «on els desequilibris del poder de gènere només poden ser avaluats mitjançant la indagació dels anhels de canvi, els desitjos i els somnis dels menys poderosos». Per tant, és necessari aclarir, també, que no totes les treballadores sexuals es troben apoderades i que, degut a això, la majoria no es concep com eixe subjecte polític i apoderat de treballadora sexual. Una circumstància que, com dèiem, és comú a totes les dones $\mathrm{i}$ en totes les professions, doncs el feminisme no cala de la mateixa manera en totes $\mathrm{i}$ tots $\mathrm{i}$ no es poden fer generalitzacions, ja que a cada persona l'envolta una realitat $\mathrm{i}$ circumstàncies personals particulars:

Tenim la idea que hem de demanar-li més a les treballadores sexuals que a la resta de dones. Estem realment en la major part de les situacions que la resta de dones en el feminisme. També hi ha gent que és feminista però que no li agrada categoritzar-se com a tal. Allò més important és que el feminisme puga tindre incidència en la vida de les dones, no que totes ens diguem feministes i participem dels moviments feministes en si. (Clarisa Velocci)

El feminisme no cala en totes les dones, però les accions i els actes de moltíssimes dones valentes, fortes i lluitadores, que, dia a dia, segueixen endavant i lluiten pels seus fills, sí [...]. Sempre som les dones les que estem tirant endavant. Si això no és feminisme... Ja em diràs què és [...]. Feminisme és lluitar per tirar endavant, per reivindicar, fer-s'hi un lloc en aquest món patriarcal. (Paula Ezkerra)

Tanmateix, el referent actual en la lluita pels drets de les treballadores sexuals el podríem situar a Barcelona, entre altres; on existeix una gran xarxa de solidaritat feminista entre les treballadores del sexe i diferents col-lectius. De fet, com comentava María Palomares, I'organització de treballadores sexuals en espais polítics està vivint el millor moment de tota la seua història, ja que veiem com estan aflorant organitzacions només de treballadores sexuals, per dialogar amb els actors polítics $i$ institucions, per reclamar drets i perquè milloren les seves condicions laborals, acompanyades per organitzacions amb una llarga trajectòria en la lluita pels drets de les treballadores.

Nosaltres vam començar al carrer, fent manifestacions, parlant amb els veïns, cridant, preguntant-li a la Policia perquè venien a molestar-nos, perquè la quinta o la sexta batuda en el dia, en un carrer de 100 metres. El primer pas directe n'ha sigut eixe, el contacte directe amb els veïns, el reclam de prou, el crit de l'espai quotidià en el barri en què vius i et coneix tot el món. La gent n'ha entès molt bé això, que ens estaven llevant l'opció que nosaltres 
triàrem per sobreviure. Després, a poc a poc, utilitzàrem les xarxes socials $i$ interactuàrem amb organitzacions pro-drets del treball sexual, però en aquest sentit, no buscàvem un suport assistencialista, no volíem que ens digueren el que havíem de fer, només que ens recolzaren en la part jurídica, en l'acompanyament institucional, però que nosaltres portarem les regnes $\mathrm{i}$ finalment, ho trobàrem, mantenint reunions, parlant amb les associacions i dient-les: nosaltres volem fer això, però sense que vosaltres tingueu la paraula, només acompanyar-nos. El següent pas després de tot això va ser la premsa escrita, programes de ràdio i televisió. (Paula Ezkerra)

Les xarxes de sororitat entre les mateixes treballadores sexuals i els diversos grups i col.lectius implicats dintre dels feminismes, han generat unes aliances que han permès a ambdós la construcció i implementació de les seues reivindicacions en el discurs públic, amb la incidència en la configuració de l'agenda política, com la presència de treballadores sexuals en les institucions (com Paula Ezkerra) i l'elaboració del programa de propostes de regulació del treball sexual per part d'elles mateixes. Aquestes aliances han permès deconstruir els imaginaris sobre els modes d'organització, estructures, funcionament i dinàmiques dels moviments feministes; donant pas a un nou model històric d'organització d'espais i xarxes de solidaritat, amb pautes de cures i dinàmiques diferents de treball i de col.laboració, integrat per treballadores sexuals:

El sindicalisme de les treballadores sexuals existeix, igual que el cooperativisme, però no en els mateixos termes que en altres collectius. Hem de deconstruir els imaginaris sobre com organitzar-se i les estructures, funcionament i dinàmiques de les organitzacions. Quan pensem en un sindicat, tenim una idea tradicionalment masculina $i$ ho relacionem amb un mode molt determinat $d$ 'associar-se [...]. En canvi, estem menyspreant $\circ$ invisibilitzant les formes de cooperatives de treball que ja existeixen entre les treballadores del sexe, és a dir, la manera en què organitzen els espais $\mathrm{i}$ les xarxes de solidaritat des de fa anys [...], però, a més a més, des del feminisme i incloent pautes de cures, amb dinàmiques diferents de treball i collaboració. (Clarisa Velocci)

Les aliances feministes hi són fonamentals per combatre eixa estigmatització social tan potent que encotilla la sexualitat femenina. Com assegura Clarisa Velocci, les treballadores sexuals han d'ocupar el lloc de portaveus, protagonistes i primera línia, malgrat que les aliades no poden abandonar i amb les aliances podem construir i generar una transformació real. Aquestes aliances amb les diferents organitzacions, han estat fonamentals per tal de crear un moviment sòlid i unes reivindicacions amb capacitat de calat social. Però, amb qui s'alien per tal de construir-les? Les aliances van des dels grans col-lectius com Hetaira i Genera, fins a les organitzacions més petites que han sorgit al ritme que han anat posicionant les seues demandes en l'espai públic, com és el cas de AFEMTRAS, consolidada l'any 2014 
i format per treballadores del polígon Villaverde/Marconi, les quals han sabut situar-se com interlocutores en la negociació d'espais públics i reclamar els seus drets.

Però el feminisme puta també està trobant altres formes d'aliar-se per lluitar contra les diferents opressions sistèmiques que pesen sobre les dones, amb la finalitat de ser d'allò més inclusiu possible, en tant a les diferents realitats socials.

El que intentarem és acostar-nos cap a altres formes d'autoorganització de gent que també hi és oprimida, com podrien ser les treballadores domèstiques, les mestresses de casa, col.lectius d'immigrants, dones musulmanes, collectius antipsiquiatrització... Gent que està treballant des de les seues realitats i que també hi són en col-lectius, tot i que no criminalitzats, però si discriminats. Creiem que ens podem acostar a aquests col.lectius per tal de crear aliances, no només des dels feminismes. També intentar apropar-nos a les dones que romanen alienes al debat, perquè no el coneixen o perquè treballen en clubs, que no arriben ni ONG ni informació, perquè si no serem ben poques i tampoc podrem ser representatives de les realitats de totes les prostitucions. (Montse Neira)

D'aquest mode, veiem com les reivindicacions originàries de l'àmbit del treball sexual, no són una lluita única pel reconeixement de la professió, els seus drets i de les treballadores sexuals com a ciutadanes i subjectes de dret; sinó que és, a més a més, una lluita contra el control social sobre la sexualitat de la dona, contra la moral que estableix la dignitat d'una dona i una professió en l'ús que es faça del cos i de la genialitat, més enllà dels discursos trafiquistes, que, com explicàvem, no fan més que simplificar la realitat i revictimitzar a les treballadores, alimentant l'estigmatització. En paraules de Carolina Justo von Lurzer:

Hi ha dos aspectes de la divisió sexual del treball que són importants per pensar en l'estigmatització específica que comporta la prostitució, en tant articulació explícita entre sexualitat i diners: la inequitativa distribució dels instruments de treball (Tabet, 2005) i la dessexualització productiva del cos (Marcuse, 1984). És a dir, no només existeix una situació històrica de "subequipament de les dones i l'existència d'un gap tecnològic entre homes i dones» (Tabet, 2005:70) en virtut de què elles, en ocupar-se de les cures dels xiquets i les tasques domèstiques, realitzarien tasques més simples que requereixen instruments simples, sinó que, a més a més, no totes les parts del cós han estat socialment configurades com a elements de treball; penis, anus i vagina -per exemple- n'han quedat exclosos. Des d'una perspectiva marcusiana, aquesta exclusió s'explica per la necessitat de des-sexualització del cos, per tal d'orientar les seues energies a l'esfera de la producció; en aquest procés el sexe genital es torna no només el lloc de concentració de la libido que habilita que la resta del cós puga ser utilitzada com a eina de treball, sinó també (i pel mateix) el sexe constitueix l'espai del «no treball» (Marcuse, 1984) i de la reproducció. De la combinació dels dos aspectes sorgeix no només la desigualtat de les dones en enfrontar-se a tasques productives 126 sinó també a l'impossibilitat de considerar productives les tasques realitzades mitjançant zones 
del cos laboralment vedades. En el marc del sexe comercial s'opera un doble desplaçament: els genitals són també utilitzats com a eina $\mathrm{i}$ les pràctiques sexuals es converteixen en un instrument productiu. (Von Lurzer, 2013:26).

Però, altrament, suposa una lluita contra l'arma més poderosa del sistema: l'estigma puta. Per tal de comprendre la profunditat de l'estigmatització en la prostitució, ens hem fet servir de l'interaccionisme simbòlic d'Erving Goffman (1998), que explica com cada rol social té assignat uns ritus d'interacció comunicativa i com aquests es van construint en funció de quin siga el seu rol en la societat. L'estigma puta, simultàniament, es divideix en altres tres estigmes: puta, com a dona que gaudeix de la seua sexualitat, puta com a mala dona i el de fill/a de puta, en el qual es combinen el ser puta com «la pitjor professió que puga existir per una dona» i l'estigma social de la mala mare, que pesa entre totes les dones.

Nosaltres realment donem i busquem un altre context sobre reflexions socials, sobre el que és el treball, no el sexual, sinó l'assalariat en general i la problemàtica al no ser reconegut el nostre dins del sistema capitalista, que no tens els beneficis que qualsevol altra treballadora té reconeguts [...] Nosaltres ara estem amb la lluita pel reconeixement d'un treball, però és un treball que ve acompanyat pel gran estigma de la humanitat sobre la dona i la seva sexualitat, que és la paraula puta. Aleshores, aquest gran estigma fa que siga més difícil, ja que les putes som considerades com a objectes, com una cosa a utilitzar per llevar-se les ganes, sense dret a reclamar... Tot això, augmenta la violència exercida cap a les treballadores sexuals i legitima aquest estigma. De vegades no la violència directa des de l'Estat, però si la violència de no reconèixer-te com a subjecte de drets, perquè les putes no podem pretendre cotitzar, cobrar, tindre fills, etc. Si trencàrem amb l'estigma puta, ens ajudaria a totes les dones del món i als homes també, perquè seria esfondrar un mur d'aquesta construcció social que tenim sobre la sexualitat. (Paula Ezkerra).

En primer lloc, l'estigma de puta, entès com a dona que gaudeix lliurement de la seua sexualitat, és el que es refereix a l'estigmatització que actua com a instrument de control de la sexualitat femenina, posant-li límits i unes pautes de com ha de ser; provocant així que la dona es puga sentir avergonyida, senta culpa pel seu comportament i s'acabe amagant (Osborne, 2004). És aquell que es refereix al «perillós» que és el plaer sexual per les dones, a què «si no es té un comportament sexualment moderat, és normal que et passen coses dolentes». El treball sexual posa tota eixa construcció en escac, ja que dessacralitza la vagina, l'entén com a element de lliure ús i apoderament econòmic i trenca amb la idea patriarcal de la virginitat com allò que determina la vàlua d'una dona. L'exemple més representatiu d'aquest estigma és el fenomen de la justificació social de la cultura de la violació, amb la pregunta del com anava vestida, si anava «provocant», etc... Un estigma de tall exclusivament femení, ja que, 
per exemple en el cas dels homes el dir puto no té la mateixa sèrie de connotacions negatives pel que fa a les dones.

El segon estigma que comentàvem és aquell que es refereix a la dicotomia de les bones i males dones, que enllaça amb l'anterior, pel fet que, en funció del nostre comportament sexual, se'ns va categoritzant. Aquesta concepció es remunta a les escriptures de la Bíblia, en la qual ja s'assenyalava a Eva com la mala dona, aquella que condueix al pecat i causa de tots els mals de la humanitat i en Maria, com la bona dona, innocent i submisa, és a dir, com el model de dona a seguir. Un mecanisme de creació d'identitats i separació entre dones que, com assenyala Dolores Juliano (Abad, 2014), actua com un «element de control social important i d'estabilitat del sistema».

En últim lloc, el tercer estigma, el de ser un fill/a de puta, és en el que es barregen dos elements molt significatius: el de puta com l'última professió que cap dona volgués exercir (el famós «cap dona neix per puta») i el de la puta com mala mare, que és una emulsió dels estigmes femenins que parlàvem anteriorment. Perquè malgrat que gran part de les treballadores sexual siguin mares, la societat patriarcal segueix considerant el ser mala mare i ser un/a fill/a de puta com els insults més greus de tota la llengua castellana. La combinació de tots els estigmes, que encara pesen sobre les treballadores sexuals, però també entre les dones que no es dediquen a aquesta professió, es visibilitza a la perfecció en la valoració que fa la societat de les prostitutes. Una valoració que es plasma en l'elaboració de les polítiques públiques que tenim al nostre abast, en les quals es discrimina, criminalitza i vulneren drets i en les quals no es tenen en compte totes les realitats del treball sexual (Arella et al., 2007), com havíem assenyalat.

\section{Les aliances amb els col-lectius pro-drets}

Altres aliances fonamentals dins de l'activisme en el treball sexual són les que s'estableixen amb els col.lectius pro-drets del treball sexual. La trajectòria d'organització de les treballadores del sexe en l'Estat espanyol es remunta a mitjans dels noranta, moment en què van gestar-se els col-lectius referents a l'actualitat, com Hetaira a Madrid; Lícit, Àmbit Dona, Lloc de la Dona i Genera en Barcelona, el Comité de Apoyo a las Trabajadoras del Sexo (CATS) a Múrcia i altres dins d'organitzacions de defensa dels drets humans, LGTBIQ+, etc. Aquests col.lectius neixen com resposta a les vulneracions de drets en el treball sexual. Però, de què tracten aquestes vulneracions, concretament? Segons assenyala l'organització Amnistia Internacional en la seua web, podem ver diferents vulneracions de drets fonamentals sota diferents aparences en els mecanismes de regulació social. Aquests hi són la discriminació 
en les lleis penals i lleis d'ordre públic, les detencions arbitràries de treballadores sexuals per les lleis anti-tracta, les lleis i polítiques de salut pública que no tenen en compte les realitats de l'estigma i la discriminació de les treballadores del sexe, el dret laboral al no reconèixer-se com una professió i no permetre'ls la sindicalització, cotització, jubilació, assistència mèdica...; les lleis d'immigració, les lleis tributàries especials (en cas que hi haja) pel treball sexual, les lleis tradicionals o religioses, les lleis internacionals que, de vegades, poden contribuir a la justificació de les violacions de drets humans en el treball sexual i la vulneració dels articles $2,3,6,7,22,23$ i 25 de la Declaració Universal dels Drets Humans.

Així doncs, són aquests col.lectius els que treballen al costat de les treballadores sexuals per tal de garantir els drets d'aquestes, com Hetaira (Madrid), Genera Derechos (Barcelona), Col-lectiu Lambda (València), APROSEX (Barcelona), El Lloc de la Dona (Barcelona), Àmbit Dona (Barcelona), Calala Fon de les Dones (Barcelona), Asociación Pro Derechos Humanos de Andalucía (APDHA), I'Asociación de Mujeres, Transexuales y Travestis como Trabajadoras Sexuales en España, AMTTTSE, a Málaga i el Comité de Apoyo a las Trabajadoras del Sexo, CATS, a Mùrcia, entre altres. Aquests estan integrats en una xarxa de suport internacional formada per altres moviments del mateix tarannà, però amb un major àmbit d'actuació, com són l'European Network for VIH/STI Prevention and Health Promotion among Migrant Sex Workers (TamPeP), Global Network of Sex Work Projects (NSWP) i el International Comitte on the Rights of Sex Workers in Europe (ICRSE).

Les organitzacions pro-drets dins de l'Estat espanyol són molt diverses entre síi comprenen un ampli espectre d'atenció a diferents realitats socials: des de, per exemple, El Lloc de la Dona, amb monges procedents de l'Església catòlica, fins a Genera que són feministes i de tall anticapitalista. Evidentment, no totes es troben sotmeses al mateix nivell $\mathrm{d}^{\prime}$ institucionalització, ni es relacionen del mateix mode amb els agents socials del seu voltant. Però sí que totes tenen uns objectius i reivindicacions comuns: la lluita per millorar les condicions de l'exercici de la prostitució, és a dir, per garantir uns drets laborals, descriminalitzar la professió, evitar les vulneracions dels drets humans i realitzar una tasca de conscienciació social contra l'estigmatització de les treballadores sexuals. Un cas representatiu d'aquesta qüestió és el Col.lectiu Lambda a València, l'únic que treballa conjuntament amb entitats marcadament abolicionistes com Médicos del Mundo, amb la que tenen un informe molt complet sobre el seu treball conjunt: Identificación sobre la realidad de la prostitución en el área metropolitana de Valencia (2015). Mitjançant aquest, es realitza una exhaustiva radiografia de la situació de la prostitució a la capital valenciana. Precisament Lambda, és el col-lectiu que ha exercit una històrica lluita pel reconeixement de les realitats de les persones transsexuals a València, resultant en la nova Llei de transsexualitat. La Llei Integral de 
Transsexualitat, a l'estil d'altres recents com les de Madrid, Andalusia, Córdoba (Argentina), la Llei d'identitat de gènere aprovada el passat any a Colòmbia, etc.; es troba encara en procés de tramitació $i$ inclourà la cirurgia de reassignació genital dins de la sanitat i la despatologització de la transsexualitat, entre altres. Una llei que, sens dubte, és un avanç en els drets del conjunt dels transgèneres, però, especialment, en el cas de les treballadores sexuals transsexuals que realitzen una recerca d'ocupacions alternatives a la prostitució:

El fet que no existisquen unes polítiques d'atenció a dones i persones transsexuals en general, es podria veure com una violència institucional [...], el fet de denegar el desenvolupament de les persones transsexuals perquè puguen portar endavant un procés transsexualitzador, el que no hi haja campanyes de sensibilització [...] Jo crec que la violència institucional s'origina per la ignorància, el no conéixer com són els processos que una persona transsexual pot portar a l'esquena durant tota la seua vida. A banda de l'estigma que puga resultar de la candidatura d'una dona transsexual a certs llocs de treball perquè, evidentment, tenen en compte l'aspecte i si la dona n'ha fet el canvi de registre o no. Si ens trobem amb un DNI amb un nom masculí, probablement l'empresa pose dificultats perquè una dona puga accedir a un lloc de treball. [...] Entorn d'un $47 \%$ de les dones que atenem són immigrants. Moltes d'aquestes no hi tenen la nacionalitat $\mathrm{i}$ com que no han pogut accedir a un DNI en què poder canviar el seu sexe i nom, es troben amb una doble trava, que és el no poder accedir al lloc de treball per la seva condició de dones transsexuals i el fet de no poder accedir a certs programes d'inclusió que es dediquen al treball sexual perquè si no té el canvi de registre fet, no pot accedir-ne. Aleshores, ens trobem amb la lluita perquè es facen accions o polítiques inclusives de les dones transsexuals en programes d'accés al treball de dones que es dediquen al treball sexual. Altre problema que ens trobem d'accés a un lloc de treball diferent del treball sexual és la remuneració. El treball sexual per moltes dones i en el cas de les dones transsexuals [...] dels 20 als 40 anys, aconsegueixen uns beneficis amb facilitat i quantitat, diferent a eixos llocs que són de 600-700 €. [...] Parlem d'uns ingressos mensuals de 2.000-3.000 € en època bona. Aleshores el nivell de vida, fins i tot les despeses que suposen tot el procés transsexualitzador d'hormonació, cirurgies, doncs és una despesa excepcional per elles. (Rafa Ruiz)

\section{La incidència política del feminisme puta}

L'efervescència dels col.lectius de treballadores sexuals, les seues reivindicacions i el fet de haver sabut posicionar-se estratègicament, ha influït en les agendes polítiques del seu voltant. Això ha suposat que alguns partits polítics s'hagin apropat a elles per tal de conèixer les seues prioritats, com és el cas de Barcelona en Comú i la Candidatura d'Unitat Popular (CUP), que han cedit l'elaboració de les seues propostes sobre prostitució a les mateixes treballadores sexuals. 
Des de la CUP portem un programa sobre treball sexual fet per nosaltres [...] ens van cridar perquè totes escriguérem el programa que volíem sobre treball sexual. I això és el que han de fer tots els partits polítics, no crear alguna cosa perquè penses que és el millor per elles, no pots saber-ho. Has de comptar amb la seua opinió i escoltar a aquestes persones. I això és el que ha fet la CUP, hem creat un programa amb tots els nostres reclams. Hem fet un debat públic, hem convidat a la gent i després, hem creat una estructura de com ens agradaria que fos la regulació del treball sexual. (Paula Ezkerra)

En aquest sentit i en altres casos, com el de València, la pressió dels col-lectius LGTBIQ+, concretament del Col.lectiu Lambda, ha permès que s'estiga elaborant una Llei Integral de Transsexualitat, que, indubtablement, afavorirà la desestigmatització de gran part de les treballadores sexuals transsexuals del País Valencià.

És un tema complex pel desconeixement que existeix sobre la realitat de les persones transsexuals i sobre les dones transsexuals i encara més, dintre del collectiu de dones transsexuals. El treball sexual de les dones transsexuals no és el mateix que les dones cisexuals, és un món prou diferent. [...] La priorització dels partits polítics és la que és, aleshores sí que informem i parlem de la realitat de les dones transsexuals, s'ho comuniquem, però ja cada partit polític és el que decideix. (Rafa Ruiz)

En l'Ajuntament de Barcelona, I'adquisició d'un gran espectre de representació de les conegudes popularment com a «forces del canvi», ha anat acompanyat de la irrupció de les treballadores sexuals, per primera vegada, en les estructures polítiques, sembrant un precedent contra l'estigmatització del treball sexual en les institucions.

Jo estic dins de les institucions, això marca una pressió política i un pes a l'hora de votar una Ilei [...] Hi ha una relació de respecte general i de canvi de perspectiva de l'imaginari social d'allò que és una treballadora sexual. Jo no sóc una pobra puta que no sé el que vull [...] es trenca amb eixe discurs de la pobra puta a la qual hem d'ajudar i la que s'ha d'adaptar a la societat. Com diu una companya: «no vaig estar mai exclosa, jo sempre n'he estat a la societat. Jo sóc mare, els meus fills van a escola». L'exclusió és real, és el sistema capitalista el que ha creat tota eixa xarxa d'estructures d'opressió perquè no pugues visibilitzar-te si no encaixes. (Paula Ezkerra)

De moment, el que ha fet l'Ada Colau és dir que no està d'acord amb aquesta ordenança que ens multa, que intentarà eliminar-la, però no ho ha fet encara. Però com que tenim la sort de tenir a la Paula Ezkerra, que és consellera del districte de Ciutat Vella, sí que la CUP està fent una mica de força i el que hem aconseguit és reconéixer el 17 de desembre com Dia Internacional del Treball sexual i sí que s'ha posat sobre la taula llevar l'ordenança. Ja veurem si la lleven o no, però el que sí que s'ha reduït és la pressió, sobretot per part de la Guàrdia Urbana. (Montse Neira) 
Veiem així, com les institucions, ja sigui mitjançant l'elaboració de polítiques públiques o els programes d'intervenció social, tenen un gran pes sobre les condicions d'acompliment del treball sexual. Unes polítiques públiques que no s'ajusten, en aquest cas, a les diferents realitats socials que envolten a la prostitució, provocant, de vegades, vulneracions de drets bàsics i/o discriminació, com veiérem en la nota d'Al. Per aquest motiu, els/les nostres informants situen que el centre de les intervencions públiques han de ser la perspectiva de gènere, ja que, segons ells/elles, els programes socials solen tindre un caràcter assistencialista, sense donar veu a les preferències de les treballadores que acudeixen a gaudir dels serveis.

El prisma de la prostitució té molts colors i molt diversos. Té una relació més institucional, en el sentit d'intervenció, d'anàlisi de polítiques públiques, que és el que les institucions valoren més, el que dota de capacitat per posicionar, de vegades, el seu discurs [de les treballadores sexuals] des d'un lloc de legitimitat [...] Una legitimitat mitjançant el treball col-lectiu de les nostres aliades principals, que són les treballadores sexuals. Nosaltres hem de fer en aquells espais on encara elles no han pogut arribar, perquè desgraciadament encara hi ha. Ser aquelles que, d'alguna manera, estiguen recordant que han d'estar i almenys portant les seves reivindicacions. Amb el nostre mètode de treballar amb la intervenció directa sí que hem sigut capaces d'arribar a aquestes companyes més aillades socialment, ja que els programes d'intervenció directa des d'una perspectiva feminista i de drets són fonamentals per l'apoderament col.lectiu [...] perquè en eixos espais, de vegades, no es compren la globalitat $\mathrm{i}$ s'enfoca des d'una perspectiva capitalista i patriarcal, resultant en què la majoria dels projectes institucionals siguen assistencialistes. (Clarisa Velocci)

\section{Conclusions}

En primer lloc, hem pogut veure que el treball sexual és una qüestió molt complexa, que implica un conjunt de realitats molt dispars, pel que, per intentar comprendre-la en tota la seua complexitat, és necessari beure de diferents disciplines teòriques com el Dret, Antropologia, Història, Filosofia, Geografia, Literatura, Filologia, Història de l'Art i Medicina. En eixe sentit, I'aproximació etnogràfica a l'espai de l'activisme en el treball sexual, en les xarxes socials, trobades i jornades i les entrevistes en profunditat, a més del marc teòric antropològic, han demostrat ser mètodes adequats per tal de complir els objectius proposats en la investigació $i$ poder confirmar la nostra hipòtesi. En termes d'investigació social, la prostitució és un camp molt estigmatitzat, en què l'accés és molt lent, el que implica submergir-se en un procés llarg i costós econòmicament. Per això, el mètode de mostreig de bola de neu de Goodman, també ha estat efectiu per contactar amb els subjectes d'estudi. Tanmateix, per tractar-se d'una realitat tan polaritzada i antagonista, hem vist com la majoria de les fonts d'estudi són 
parcials i esbiaixades, pels interessos oposats dels diferents posicionaments sobre prostitució. Això es deu al fet que el debat social sobre el treball sexual encara continua dicotomitzat $i$ inserit en un maniqueisme abolicionisme/legalització (amb els seus accents diferents dins de cada postura), atorgant un major espai a la diferència i deixant una bretxa que sembla no haver-se estret en els últims 30 anys. Del mateix mode, encara s'està prioritzant l'argumentació teòrica de les postures del debat, redundant en les mateixes fins a l'enfrontament, en vegada de donar veu a les treballadores sexuals, que són les protagonistes de les realitats socials abordades i les que més poden aportar a aquestes.

Respecte a les actuacions institucionals, dins dels programes d'intervenció social, hem detectat tres fenòmens importants. El primer és que les treballadores se senten alienades, perquè s'opera de la mateixa forma amb les víctimes de tracta que amb les treballadores del sexe, pel que acaben acudint als programes dels col.lectius pro-drets. El segon és que, en ser considerades totes com a víctimes de tracta, es produeix un falsejament estadístic, ja que no es distingeix i s'engloba a totes en la mateixa realitat. En últim lloc, el tercer, és que, en l'oferta d'ocupacions alternatives a la prostitució, es reprodueixen la feminització de la pobresa i els treballs de cures i la precarització laboral femenina; ja que la mitjana del sou $d^{\prime}$ aquests treballs és de $687 €$ (segons ens va explicar Montse Neira), el que provoca que es torne a l'exercici de la prostitució.

A banda d'aquestes institucions, dins de la controvèrsia que suscita el treball sexual en l'esfera pública, trobem alguns agents amb un pes fonamental en la configuració de les realitats socials de la prostitució: els mitjans de comunicació, els partits polítics i l'acadèmia. En el cas de la política, cada partir ha anat elaborant el seu posicionament de manera aliena a la seua ideologia, si tenim en compte el tradicional espectre esquerra-dreta, com es podria pensar de forma apriorística, sent majoritàries les posicions abolicionistes (per part de PP, PSOE i IU), deixant la legalització als programes de Ciutadans (amb els seus matisos de beneficis cap als empresaris i no cap a les treballadores sexuals) i la CUP (els/les únics/es que han parlat amb elles, cedint-les les seues propostes de treball sexual del partit) i quedant Podemos com l'únic que no s'ha definit completament en aquest aspecte. Tot això, ens ajuda a entendre la naturalesa abolicionista del marc jurídic de l'Estat espanyol pel que fa a la prostitució, doncs PP i PSOE són els que solien ocupar, tradicionalment, les majories absolutes dels espais d'influència i configuració del poder legislatiu.

D'altra banda, les xarxes de solidaritat entre les mateixes treballadores sexuals i els diversos grups i col.lectius implicat dintre dels feminismes, han generat unes aliances que han permès a ambdós la construcció i implementació de les seves reivindicacions en el discurs públic, amb la seua incidència inevitable en la configuració de l'agenda política. Per tant, els 
instruments de projecció pública dels que es serveixen les treballadores sexuals són aquestes aliances que estableixen amb altres col.lectius, els veïns i veïnes, l'ús estratègic que fan dels mitjans de comunicació i el seu posicionament dins de les institucions, ja siga amb la seua participació directa (com Paula Ezkerra en la CUP) o indirecta, mitjançant la implementació de les seues reivindicacions en els collectius pro-drets, que les traslladen i situen en les institucions. L'organització de les treballadores sexuals i la seua incidència a tots els nivells socials és l'exemple més representatiu del canvi de paradigma dels moviments feministes, en què les xarxes de solidaritat entre dones estan provocant la deconstrucció de les dinàmiques $i$ modes de fer tradicionalment masculinitzats, i s'estan imposant les xarxes de cures i d'afecte. Aquestes xarxes sorgeixen com resposta a una sèrie d'opressions (interseccionalitat) que no solen ser tingudes en compte pels corrents feministes tradicionals (l'estigma a tots els nivells), les quals seria interessant incloure en les agendes polítiques de tots els feminismes, ja que tenen un caràcter social transversal. Així, un dels reptes dels feminismes que encara queda pendent, seria projectar una mirada integradora cap al treball sexual, en la que es fomente I'aliança entre dones i amb la que esbiaixe l'estigma, que ens classifica d'acord a la nostra sexualitat i suposa un dels fonaments més poderosos sobre els que s'erigeix el patriarcat.

En aquest sentit, les principals organitzacions pro-drets del treball sexual dins de l'Estat espanyol són Hetaira (Madrid), GeneraDerechos (Barcelona), Col-lectiu Lambda (València), APROSEX (Barcelona), El Lloc de la Dona (Barcelona), Àmbit Dona (Barcelona), Calala Fons de les Dones (Barcelona), Asociación Pro Derechos Humanos Andalucía (APDHA), I'Asociación de Mujeres, Transexuales y Travestis como Trabajadoras Sexuales en España, AMTTTSE, en Málaga i el Comité de Apoyo a las Trabajadoras del Sexo, CATS, en Múrcia. Aquestes són molt diverses i comprenen un ampli espectre d'atenció a diferents realitats socials. A més a més, no totes estan sotmeses al mateix nivell d'institucionalització, ni es relacionen del mateix mode amb els agents socials del seu voltant. Allò que tenen en comú és la lluita per millorar les condicions de l'exercici de la prostitució, és a dir, garantir uns drets laborals, descriminalitzar la professió, evitar les vulneracions dels drets humans i realitzar una tasca de conscienciació social contra l'estigmatització de les treballadores sexuals.

Altrament, existeixen tres qüestions fonamentals que han motivat aquesta investigació i que queden pendents de resoldre en l'esfera pública, respecte al treball sexual. La seua resolució ens ajudaria a poder integrar, de manera horitzontal i respectuosa, les realitats del treball sexual dins de l'agenda pública: la lluita contra l'estigmatització, l'elaboració de lleis integradores per la protecció dels drets de les treballadores del sexe i la visibilització dels diferents tipus de prostitució. Per això, necessitem solucions integradores per part dels partits polítics, en conjunt amb els moviments pro-drets, ONG i treballadores, la formació de 
la Policia en matèria de gènere, la descriminalització de la prostitució, l'eliminació de les sancions als clients, perquè encareix les condicions de seguretat de les treballadores; i la visibilització dels diferents tipus de prostitució, en la qual hi ha tantes realitats com persones i el paper fonamental que tenen en aquesta els mitjans de comunicació i l'acadèmia.

Consegüentment, els mitjans de comunicació, que són els que projecten la imatge de les realitats de la prostitució, han de canviar els seus discursos, ja que estan basats en la reproducció d'estereotips que estigmatitzen a les dones que exerceixen la prostitució i que afavoreixen la vulneració dels seus drets de ciutadania, en àmbits com les lleis penals, les lleis d'ordre públic, les lleis anti-tracta, polítiques de salut pública, el dret laboral, lleis d'immigració, lleis tributàries, lleis tradicionals i religioses i les lleis internacionals. El treball sexual s'ha d'abordar en tota la seua complexitat social, sent les mateixes treballadores sexuals qui gestionen i elaboren els seus discursos; assumint els/les periodistes la tasca de donar veu als/les que no la tenen, mitjançant de forma responsable en les controvèrsies $i$ respectant el codi deontològic, però, sobretot, a les treballadores sexuals.

En eixe sentit, també l'acadèmia juga un paper molt important, deconstruint els imaginaris socials sobre la prostitució, però el seu abast és molt limitat, ja que són poques les persones que es posicionen dins d'ella. Encara, els enfocaments trafiquistes de la prostitució són els que tenen més pes en la subvenció de projectes d'investigació social, el que provoca que la producció d'investigacions amb un discurs de defensa de drets del treball sexual queden relegades a l'autogestió econòmica de les investigadores que formem part de l'acadèmia i multiplica l'estigmatizació de les treballadores sexuals en l'espectre de projecció social en què l'acadèmia té influència. És necessària la creació d'aliances feministes sòlides també en l'espai acadèmic, per tal d'evitar les apropiacions del discurs, trencar amb els estatus socials elitistes derivats de la mateixa (que no permeten l'accessibilitat integral de la societat al coneixement) i entendre la conquista de drets de les treballadores sexual i la seua visibilització social com una tasca col-lectiva, però en les que elles siguin les protagonistes.

\section{Bibliografia}

$A B A D$, Itziar (2014): «Si la prostitución no fuera acompañada del rechazo social, podría resultar atractiva para más personas». Pikara Magazine.

Auntament de Barcelona (2015): El tratamiento de la prostitución y la trata con fines de explotación sexual en los medios de comunicación. Recomendaciones, Barcelona, s.n.

AMNISTía InTERNACIONAL (2015): Nota aclaratoria sobre el posicionamiento de Al, en defensa de los DDHH de las personas que ejercen la prostitución, s.l.: s.n. 
Arella, Celeste et al. (2007): Los pasos (in)visibles de la prostitución, Barcelona, Virus.

Castells, Manuel, (2009): Comunicación y poder, Madrid, Alianza Editorial.

CHAPKIS, Wendy (1997): Live Sex Acts. Women performing erotic labour, Londres, Casell.

CluA, Anna (2015): «La batalla simbólica de las prostitutas. El papel de la comunicación»,

Revista Internacional de Comunicación y Desarrollo, №1, pp. 139-150.

DAICH, Debora, (2012): «¿Abolicionismo o reglamentarismo? Aportes de la antropología

feminista para el debate local sobre la prostitución». RUNA, 1 (XXXIII), pp. 71-84.

Despentes, Virgine (2009): Teoría King Kong, Barcelona, Melusina.

EMAKUNDE, (2010): Reflexión estratégica sobre el fenómeno de la prostitución en la CAPV, s.l., Emakumearen Euskal Erakunde.

Espejo, Beatriz (2009): Manifiesto puta, Barcelona, Bellaterra.

FonseCA, Carlos y Quintero, María Luisa (2009): «La Teoría Queer: la de-construcción de las sexualidades periféricas», Sociológica. N69, pp. 43-60.

GaraizÁbal, Cristina, Juliano, Dolores y Neira, Montse (2009): Nosotras, las malas mujeres.

Disponible en: http://www.feministas.org/nosotras-las-malas-mujeres-debates.html [Consultado el 15 de mayo de 2017]

GoffMAN, Erving (1998): Estigma, Buenos Aires, Amorrortu.

GüEREÑA, Jean Luis (2003): La prostitución en la España contemporánea, Madrid, Marcial Pons.

HaraWAY, Donna (1991): Ciencia, cyborgs y mujeres: la reinvención de la naturaleza, Barcelona, Paidós.

JULIANO, Dolores (2002): La prostitución: el espejo oscuro, Barcelona, Icaria.

Justo von LURzER, Carolina (2013): Sex, love and money. Socio-sexual imaginary in television representations of prostitution in Argentina, Buenos Aires, CECYP.

LAGARDE, Marcela (2006): «Pactos entre mujeres y sororidad», Aportes para el debate, pp. 123-135.

LEÓN, Manuela (1997): Poder y empoderamiento de las mujeres. Primera ed. Bogotá: TM Editores.

LÓPEZ-RIOPEDRE, José (2012): «Una aproximación etnográfica a la prostitución: cuando las trabajadoras sexuales hablan de los clientes», RES. N 18, pp. 31-62.

LUKES, Steven (1986): Power, Readings in Social and Political Theory. Oxford: Basil Blackwell. MAQUEDA, María Luisa (2008): La prostitución en el debate feminista: ¿̇otra vez el abolicionismo?.

En: Problemas actuales del derecho penal y de la criminología: estudios penales en memoria de la Profesora Dra. María del Mar Díaz Pita. Editorial Dykinson: Barcelona, pp. 833-856. 
MARCUSE, Herbert (1984): Eros y civilización, Barcelona, Ariel.

MARQUÉs, Josep Vicent (1981): ¿¿Qué hace el poder en tu cama. s.l.: Ediciones 2001.

MÉDICOS DEL MUNDO (2015): Identificación sobre la realidad de la prostitución en el área metropolitana de Valencia, Valencia.

Mestre, Ruth (2004): Las caras de la prostitución en el Estado español: entre la Ley de Extranjería y el Código Penal. En: R. Osborne, ed. Trabajador@s del sexo. Derechos, migraciones y tráfico en el siglo XXI, Barcelona, Bellaterra.

NeIRA, Montse (2012): Una mala mujer, Barcelona, Plataforma.

Nieto, José Antonio (2011): Sociodiversidad y sexualidad, Madrid, Talasa.

OSBORNE, Raquel (2004): Trabajador@s del sexo, Barcelona, Bellaterra.

Parlamento EUROPEO (2000): Informe sobre explotación sexual y prostitución, Disponible en: http://www.europarl.europa.eu/sides/getDoc.do?pubRef=-//EP//TEXT+REPORT+A72014-0071+0+DOC+XML+VO//ES [Consultado el 15 de mayo de 2017]

Ramos, Inmaculada (2016): Modelos legales del trabajo sexual. Granada, Diálogos sobre el sexo de pago, Universidad de Granada.

TABET, Paola (2005): Las manos, los instrumentos, las armas. En: El patriarcado al desnudo. Tres feministas materialistas, Buenos Aires, Brecha Lésbica.

TejerINA, Benjamín (2005): «Movimientos sociales, espacio público y ciudadanía: Los caminos de la utopía». Revista Crítica de Ciências Sociais.

Recibido el 13 de marzo de 2017

Aceptado el 19 de mayo de 2017

BIBLID [1 139-1219 (2017) 22: $119-137]$ 